\title{
HUBUNGAN LAMA PEMASANGAN KATETER DENGAN KEJADIAN INFEKSI SALURAN KEMIH PADA PASIEN DI RUANG PENYAKIT DALAM RUMKIT TK II DR. SOEPRAOEN MALANG
}

\author{
Karisma Dwi Ana ${ }^{1)}$, Nunuk Yuli Riwayati ${ }^{2)}$, Siska Febri Jayanti ${ }^{3)}$ \\ 1),2),3) Sekolah Tinggi Ilmu Kesehatan Husada Jombang \\ E-mail: rismakna@gmail.com
}

\begin{abstract}
Urinary tract infections are included by pathogenic microorganisms associated with objects in the urinary tract. Catheter placement is one of the interventions given to patients with urinary tract disorders. This can save lives, especially if the urinary tract is blocked or if the patient is unable to make urine transfer smoothly. This study uses a correlational analytic research design using a cross sectional design. The sample of this study was a patient with a catheter in the disease room in Hospital LevelII Dr. Soepraoen as many as 38 people by using side-taking techniques with accidental sampling. The measuring instrument used was an observation sheet. The results of this study indicate that the majority of respondents experienced a catheter installation time of two days, as many as 10 respondents (26.3\%), and the majority of respondents did not experience urinary tract infections as many as 36 respondents (94.7\%).Spearman rail test results obtained significance values $<0.05$ then $H 1$ is accepted. It can be concluded that there is a long association between catheter placement and the incidence of urinary tract infections in patients in the disease room in Hospital LevelII Dr. Soepraoen. Catheter installation should be relatively short, if the installation of a catheter in a long time can result in a bigher incidence of urinary tract infections.
\end{abstract}

Keywords : Duration of catheterization; urinary tract infection occurrence.

\begin{abstract}
ABSTRAK
Infeksi saluran kemih di akibatkan oleh mikroorganisme patogen yang berkaitan adanya suatu benda asing didalam saluran perkemihan. Pemasangan kateter merupakan salah satu intervensi yang diberikan kepada pasien dengan gangguan saluran perkemihan. Tindakan ini dapat menyelamatkan kehidupan, khususnya bila saluran kemih tersumbat atau bila pasien tidak dapat melakukan pengeluaran urin dengan lancar.Penelitian ini menggunakan desain penelitian analitik korelasional dengan pendekatan rancangan cross sectional. Sampel penelitian ini adalah pasien dengan pemasangan kateter di Ruang Penyakit Dalam Rumkit Tk II Dr. Soepraoen sebanyak 38 orang dengan menggunakan teknik pengambilan samping dengan accidentalsampling. Alat ukur yang digunakan ialah lembar observasi. Hasil penelitian ini menunjukkan bahwa sebagian besar responden mengalami lama waktu pemasangan kateter selama dua hari yaitu sebanyak 10 responden (26,3\%), serta sebagian besar responden tidak


mengalami kejadian infeksi saluran kemih yaitu sebanyak 36 responden (94,7\%). Hail uji spearman rho diperoleh nilai signifikasi $<0,05$ maka H1 diterima. Hal ini dapat disimpulkan bahwa ada hubungan lama pemasangan kateter dengan kejadian infeksi saluran kemih pada pasien di ruang penyakit dalam Rumkit Tk II Dr. Soepraoen. Pemasangan kateter sebaiknya dalam wakturelatif singkat, bila pemasangan kateterdalam waktu yang lama dapat mengakibatkan angka kejadian infeksi saluran kemih semakin tinggi.

Kata Kunci :Lama pemasangan kateter; kejadian infeksi saluran kemih.

\section{PENDAHULUAN}

Infeksi Saluran Kemih (ISK) akibat kateterisasi merupakan penyebab utama dari infeksi nosokomial dan 80\% diperoleh dari penggunaan katater urin (Asbone dkk, 2017). Pasien yang terpasang kateter setiap hari mengalami peningkatan infeksi sebanyak 5\%. Hal tersebutdisebabkan karena bakteriuria bisa muncul sesudah hari kedua pemasangan kateter urin dan resiko berkembangnya bakteriuria meningkat seiring dengan durasi kateterisasi (Budiarti dkk, 2012).

Menurut WHO menyatakan dalam Safitri (2016), Infeksi saluran kemih adalah penyakit infeksi kedua yangtersering terjadi setelah penyakit saluran pernafasan. Sebanyak 8,3 juta kasus infeksi saluran kemih dilaporkan per tahun terjadi pada perempuan, 4,2 juta kasus terjadi pada laki-laki. Di Indonesia prevalensi infeksi saluran kemih masih cukup tinggi, menurut perkiraan Departemen Kesehatan Republik
Indonesia, jumlah penderita infeksi saluran kemih di Indonesia adalah 90-100 kasus per 100.000 penduduk pertahun nya (Depkes Ri, 2016 dalam Darsono, Mahdiyah dan Sari 2016).

Tahun 2017 Di jawa timur terdapat 10.000 kasus infeksi saluran kemih, Sebagian besar penderitainfeksi saluran kemih adalahwanita yaitu sekitar 6.730 orang serta sebagian kecil penderitnya adalahlaki-laki 4511 orang. Di kabupaten Malang tahun 2017, prevalensi kejadian pasien infeksi saluran kemih sangat tinggi sekitar 2.150 orang dan penderitapaling banyak adalah wanita. Sedangkan di Rumkit Tk II Dr. Soepraoen Malang, tahun 2017 infeksi salurankemih merupakan angka kejadian paling tinggi, sekitar 35 orang wanita (55\%)sering mengalami ISK dan sekitar 15 orang lakilaki (45\%) mengalami ISK. Berdasarkan studi pendahuluan bulan Januari 2018 oleh penelitibahwa terdapat 50 pasien di lakukakan pemasangan kateter di ruang 
Penyakit Dalam Rumkit TK II Dr. Soepraoen.

Adanya mikroorganisme patogen dalam saluran kemih dapat mengakibatkan tanda-tanda infeksi saluran kemih (Newman, 2010). Pemasangan kateter yang relative singkat dapat menurunkan kejadian infeksi saluran kemih. Perawat berperan penting dalam melakukan pemasangan dan perawatan kateter, sehingga diharapkan perawat memiliki pengetahuan yang baik dalammelakukan pemasangan dan perawatan katetersesuai dengan standar operasioal prosedur yang ditentukan (Putri dkk, 2011)

Menurut penelitianRarung (2010) menyatakansekitar 3 - $33 \%$ Insiden infeksi saluran kemih meningkat sesuai dengan lamanya pemasangan kateter. Prosedur pemasangan kateter harus steril dan kateter harus bebas dari bakterihal tersebut sebagai upaya pencegahan kejadianinfeksi saluran kemih.

\section{METODE PENELITIAN}

Desain penelitian yang digunakan adalah penelitian analitik korelasional dengan pendekatan rancangan cross sectional. Sampel dalam penelitian ini adalah pasien dengan pemasangan kateter di Ruang Penyakit Dalam Rumkit Tk II Dr. Soepraoen sebanyak 34 responden dengan menggunakan teknikpengambilan sampling menggunakan total sampling. Alat ukur yang digunakan ialah lembar observasi.Uji analaisis data dengan menggunakan uji spearman rho.

\section{HASIL}

Tabel 1. Distribusi frekuensi karakteristik responden berdasarkan usia, jenis kelamin,dan penyakit penyerta.

\begin{tabular}{lcc}
\hline Karakteristik responden & f & $\mathbf{( \% )}$ \\
\hline Usia : & & \\
Usia 20-30 tahun & 7 & 18,4 \\
Usia 31-40 tahun & 15 & 39,5 \\
Usia 41-50 tahun & 16 & 42,1 \\
Jenis Kelamin : & & \\
Perempuan & 13 & 34,2 \\
Laki-laki & 25 & 65,8 \\
& & \\
Penyakit Peserta : & 14 & 36,8 \\
Diabetes melitus & 18 & 47,4 \\
Hipertensi & 6 & 15,8 \\
Gangguan Fungsi ginjal & & \\
& & \\
Total & 38 & 100 \\
\hline
\end{tabular}

Frekuensi karakteristik responden berdasarkan usia, sebagian besar responden berusia antara 41-50 tahun yaitu sebanyak 16 responden (42,1\%), sebagian besar responden berjenis kelamin laki-laki yaitu sebanyak25 responden $(65,8 \%)$, dan sebagian besar responden mempunyai penyakit penyerta 
hipertensi yaitu sebanyak 18 responden $(47,4 \%)$.

Tabel 2. Distribusi lama waktu pemasangan kateter di ruang peyakit dalam Rumkit TK II Dr. Soepraoen Malang

\begin{tabular}{lcc}
\hline \multicolumn{1}{c}{$\begin{array}{c}\text { Lama waktu } \\
\text { pemasangan kateter }\end{array}$} & $\mathbf{f}$ & $\mathbf{( \% )}$ \\
\hline Satu hari & 4 & 10,5 \\
Dua hari & 10 & 26,3 \\
Tiga hari & 8 & 21,1 \\
Empat hari & 4 & 10,5 \\
Lima hari & 6 & 15,8 \\
Enam hari & 3 & 7,9 \\
Tujuh hari & 3 & 7,9 \\
\multicolumn{1}{c}{ Total } & 38 & 100 \\
\hline
\end{tabular}

BerdasarkanTabel 2 diketahui bahwa sebagian besar responden mengalami lama waktu pemasangan kateter selama dua hari yaitu sebanyak 10 responden (26,3\%), dan sebagian kecil responden mengalami lama waktu pemasangan kateter selama enam hari dan tujuh hari yang masing-masing sebanyak 3 responden $(7,9 \%)$.

Tabel 3. Distribusi kejadian infeksi saluran kemih di ruang peyakit dalam Rumkit TK II Dr. Soepraoen Malang

\begin{tabular}{lcc}
\hline $\begin{array}{c}\text { Kejadian infeksi saluran } \\
\text { kemih }\end{array}$ & f & $\mathbf{( \% )}$ \\
\hline Infeksi & 36 & 94,7 \\
Tidak tejadi infeksi & 2 & 5,3 \\
$\quad$ Total & 38 & 100 \\
\hline
\end{tabular}

BerdasarkanTabel 3 diketahuibahwa sebagian besar responden tidak mengalami infeksi saluran kemih yaitu sebanyak 36 responden $(94,7 \%)$ dan sebagian kecil responden mengalami infeksi saluran kemih yaitu sebanyak 2 responden $(5,3 \%)$.

\section{PEMBAHASAN}

Lama Pemasangan Kateter yang Dilakukan Perawat Di Ruang Penyakit Dalam Rumkit Tk II Dr.

\section{Soepraoen}

Berdasarkan penelitian ini ditemukan bahwa sebagian besar responden mempunyai lama waktu pemasangan kateter selama dua hari yaitu sebanyak 10 responden $(26,3 \%)$, dan sebagian kecil responden mengalami lama waktu pemasangan kateter selama enam hari dan tujuh hari yang masing-masing sebanyak 3 responden $(7,9 \%)$.

Pemasangan kateter merupakan salah satu solusi tindakan medis untuk mengeluarkan urin dari kandung kemih hal tersebut disebabkan karena pasien tidakmampu mengeluarkan urin secara spontan.

Peran perawat untuk mengurangi dampak dari pemasangan kateter adalah dengan memberikan pemasangan dengan baik 
dan perawatan kateter yang berkualitas. Selain kualitas perawatan yang diberikan oleh perawat, faktor lain yang dapat menyebabkan infeksi saluran kemih adalah faktor hospes itu sendiri. Pasien yang terpasang kateter dan memiliki umur yang tergolong lanjut dan anak-anak akan mempunyai risiko yang lebih besar daripada dewasa. Hal ini karena lansia sudah terjadi penurunan daya imun dan pada anak-anak belum memiliki daya imun sebaik orang dewasa. Begitu pula pada wanita, mempunyai risiko yang tinggi terjadi infeksi saluran kemih karena uretra, vagina dan anus terletak berdekatan. Perawat melakukan pemasangan kateter harus berdasarkan standar operasional pemasangan kateter dan prosedur pencegahan infeksi saluran kemih. Untuk menilai kedua unsur tersebut, melakukan observasi pada perawat setelah pemasangan kateter serta mengkaji keadaan pasien yang terpasang kateter setelah dilakukan tindakan perawatan kateter. Observasi dilakukan selama pasien mulai terpasang kateter sampai dilepas atau hari kesepuluh. Hal ini dilakukan karena kejadian infeksisaluran kemih terjadi setelah pasien dirawat minimal 3x24 jam.
Dalam penelitian ini menunjukkan sebagian besar responden yang terpasang kateter pada saat penelitian dalam waktu yang relative singkat. Hal ini dikarenakan oleh indikasi pemasangan kateter uretra yang membutuhkan waktu yang tidak begitu lama. Pemasangan kateter dalam jangka waktu lama dapat mengakibatkan terjadinya infeksi. Dalam penelitian Setyabakti dan Sari (2015) menyatakan bahwa bakteriuria ditemukan sebanyak 44\% pada pasien setelah 72 jam (3 hari) pertama pemasangan kateter urin indwelling. Infeksi saluran kemih tidak hanya disebabkan oleh bakteri Staphylococcus aureus. Ada beberapa mikroorganisme yang dapat menyebabkan bakteriuri, diantaranya yaitu, Escherichia coli, Klebsiella, Proteus, Pseudomonas, Enterobacter, Serratia, dan Streptococcus. Mikrorganisme ini kemudian membentuk biofilm di sepanjang permukaan eksternal kateter (Semardana, 2014).

Kejadian Infeksi Saluran Kemih Pada Pasien Di Ruang Penyakit Dalam Rumkit Tk II Dr. Soepraoen

Berdasarkanhasil penelitian menunjukkan bahwasebagian besar responden tidak mengalami infeksi saluran kemih yaitu sebanyak 36 responden $(94,7 \%)$ dan 
sebagian kecil responden mengalami infeksi saluran kemih yaitu sebanyak 2 responden $(5,3 \%)$.

Infeksi Saluran Kemihsering terjadi setelah pemasangan kateter urin. Hal ini dapat disebabkan karena bakteriuria bisa muncul sesudah hari kedua pemasangan kateter urin dan resiko berkembangnya bakteriuria meningkat seiring dengan durasi kateterisasi (Budiarti dkk, 2012).Prosedur pemasangan kateter harus sesuai dengan standar yang ditentukan, hal ini menjamin dilaksanakannya teknik yang benar, dan di anjurkan dilaksanakan oleh perawat yang mendapat pelatihan khusus. Kejadianinfeksi saluran kemih dapat terjadi apabila pemasangan kateter tidak dilakukan sesuai dengan standar operasional prosedur.

Infeksi saluran kemih adalah infeksi yang sering menyerang pria maupun wanita dari berbagai usia dengan berbagai tampilan klinis dan episode. ISK sering menyebabkan morbiditas dan dapat secara signifikan menjadi mortalitas. Walaupun saluran kemih normalnya bebas dari pertumbuhan bakteri, bakteri yang umumnya naik dari rektum dapat menyebabkan terjadinya ISK (EAUI, 2015).
Hasil penelitian ini menunjukkan 2 responden mengalami infeksi saluran kemih, hal ini bisa dikarenakan personal hygine kurang menjaga kebersihan setelah melakukan pemasangan kateter urine. Bisa juga dikarenakan oleh faktor usia, jenis kelamin ataupun penyakit penyerta, serta resiko terjadinya infeksi saluran kemih dapat semakin tinggi apabila prosedur pemasangan tidak dilakukan sesuai dengan standar operasional prosedur.

Hubungan Pemasangan Kateter yang Dilakukan Perawat dengan Kejadian Infeksi Saluran Kemih Pada Pasien Di Ruang Penyakit Dalam Rumkit Tk II Dr. Soepraoen

Hasil Uji Spearman,s rhodiperoleh nilai signifikasi < 0,05 maka yang H0 ditolak dan H1 diterima yang artinya ada hubungan lama pemasangan kateter dengan kejadian infeksi saluran kemih pada pasien di ruang penyakit dalam Rumkit Tk II Dr. Soepraoen dengan Nilai koefisien korelasi spearman sebesar 0,00 .

Prosedur dalam melakukan pemasangan kateter perlu memperhatikan teknik aseptik dan benar sehingga tidak menimbulkan iritasi atau trauma pada saluran kemih yang dapat menjadi 
sumber infeksi. Serta lamanya waktu pemasangan kateter sebaiknya tidak terlalu lama, karena semakin lama pemasangan kateter dapat mengakibatkan angka kejadian infeksi saluran kemih semakin tinggi. Pemasangan kateter pada pasien sebaiknya tidak lebih dari 7 hari , bila lebih dari 7 hari sebaiknya dilakukan penggantian pemasangan kateter baru.

Perawatan kateter harus berdasarkan standart operasional prosedur gunamengurangi kejadian infeksi saluran kemih pada pasien. Selain itu faktor lain yang menjadi faktor predisposisi adalah diagnosa medis. Diagnosa medis yang memiliki risiko tinggi terjadinya ISK adalah CRF dan DM. Serta lingkungan sekitar yang banyak mengandung mikroorganisme juga menjadi salah satu faktor predisposisi penyebab infeksi, sehingga setiap saat mikroorganisme dapat masuk melalui kateter yang bersinggungan dengan alat tenun yang kotor.

\section{KESIMPULAN}

Lama pemasangankateter di Ruang Penyakit Dalam Rumkit Tk II Dr. Soepraoen, termasuk dalam waktu yang relatif singkat yaitu selama dua hari, sebanyak 10responden (26,3\%) dari
38responden.Dan sebanyak 36 responden (94,7\%)dari 38 respondenSoepraoen tidak mengalami kejadian infeksi saluran kemih.

\section{SARAN}

Diharapkan memberikan informasi pada rumah sakit khususnya perawat diRumkit TK II Dr. Soepraoen, untuk selalu memonitoring tanda-tanda infeksi, selalu menerapkan prosedur aseptikdalam melakukan tindakan pemasangan kateter kepada pasien.

\section{REFERENSI}

Franky. (2014). Hubungan Antara Lama Waktu Terpasang Kateter Dengan Kecemasan Pada Klien Yang Terpasang Kateter Urethra Di Bangsal Rawat Inap Dewasa kelas III RS PKU Mubammadiyah Yogyakarta. Karya Tulis Ilmiah. Tidak Dipublikasikan. UMY : Yogyakarta

Handoko, Riwidoko. (2013). Statistik Kedokteran. Yogyakarta : Rahima Press.

Semardana,WG.I. (2014). Infeksi Saluran Kemih Akibat Pemasangan Kateter Diagnosis dan Penatalaksanaan. Fakultas Kedokteran Universitas Udayana. Denpasar. Bali

Setyabakti, Sari. (2015). Perbedaan Risiko Infeksi Nosokomial Saluran Kemih Bersadarkan Kateterisasi Urin,Umur, Dan Diabetes Mellitus. Departemen Epidemiologi Fakultas Kesehatan Masyarakat Universitas Airlangga Surabaya, Jawa Timur

Putri dkk, (2011). Faktor-Faktor yang Berpengaruh Terbadap Kejadian Infeksi Saluran Kemih Pada Pasien Rawat Inap 
Usia 20 Tabun Ke Atas Dengan Kateter Menetap di RSUD Tugurejo Semarang. Jurnal. Diakses 12 Januari 2018.

Prabowo \& Pranata.(2014). Buku Ajar Asuban Keperawata Sistem Perkemiban. Jember: Penerbit Nuha Medika
Setiadi.(2013). Konsep dan Praktik Penulisan Riset Keperawatan. Edisi 2. Yogyakarta: Graha Ilmu.

Septiari,B.B. (2012). Infeksi Nosokomial. Jakarta : Nuha Medika

Sukandar E., (2009). Infeksi Saluran Kemih Pada Pasien Dewasa . Dalam Buku Ajar Penyakit Dalam Jilid 2 Edisi 5.Jakarta: Balai Penerbit FKUNPAD. 